\title{
Synthesis, Characterization and Antibacterial Activity Studies of Some Transition Metal Chelates of Mn(II), Ni(II) and Cu(II) with Schiff Base Derived from Diacetylmonoxime with $O$ - phenylenediamine
}

\author{
Abdulsalam Hamil* (iD), Khalifa Mosbah Khalifa, Arabya Abdelsalam Almutaleb (iD, Mariam Qasim \\ Nouradean
}

Department of Chemistry, Faculty of Science, Sebha University, Sebha, Libya

A R T I C L E I N F O

Received: 30 November 2019

Revised: 19 December 2019

Accepted: 06 January 2020

Available online: 08 January 2020

\section{K E Y W O R D S}

\section{Schiff base}

Chelates

(2E, 3E)-3-((2-amino phenyl) imino) butane-2one oxime

\section{A B S T R A C T}

In this study, the transition metal chelates of Mn(II), Ni(II) and $\mathrm{Cu}(\mathrm{II})$ with Schiff base were synthesized and characterized. The elemental analysis data showed that, the isolated chelates are in 1:1 [M:L] ratio. The molar conductance values revealed that the chelates are none electrolyte in nature. The results of magnetic moment measurements demonstrated that, the chelates of $\mathrm{Mn}$ (II) and $\mathrm{Cu}(\mathrm{II})$ have unpaired electrons and chelates of $\mathrm{Ni}(\mathrm{II})$ is diamagnetic. The infrared spectral data displayed the main coordination sites of (2E, 3E)-3-((2-aminophenyl)imino)butan-2-one oxime towards $\mathrm{Mn}(\mathrm{II}), \mathrm{Ni}(\mathrm{II})$ and $\mathrm{Cu}(\mathrm{II})$ ions. The electronic spectrum results of the Schiff base ligand and its chelates suggest that the Mn(II) and $\mathrm{Cu}$ (II) chelates have octahedral structure and $\mathrm{Ni}(\mathrm{II})$ chelate is square planar.

\section{GRAPH I C A L A B S TRACT}

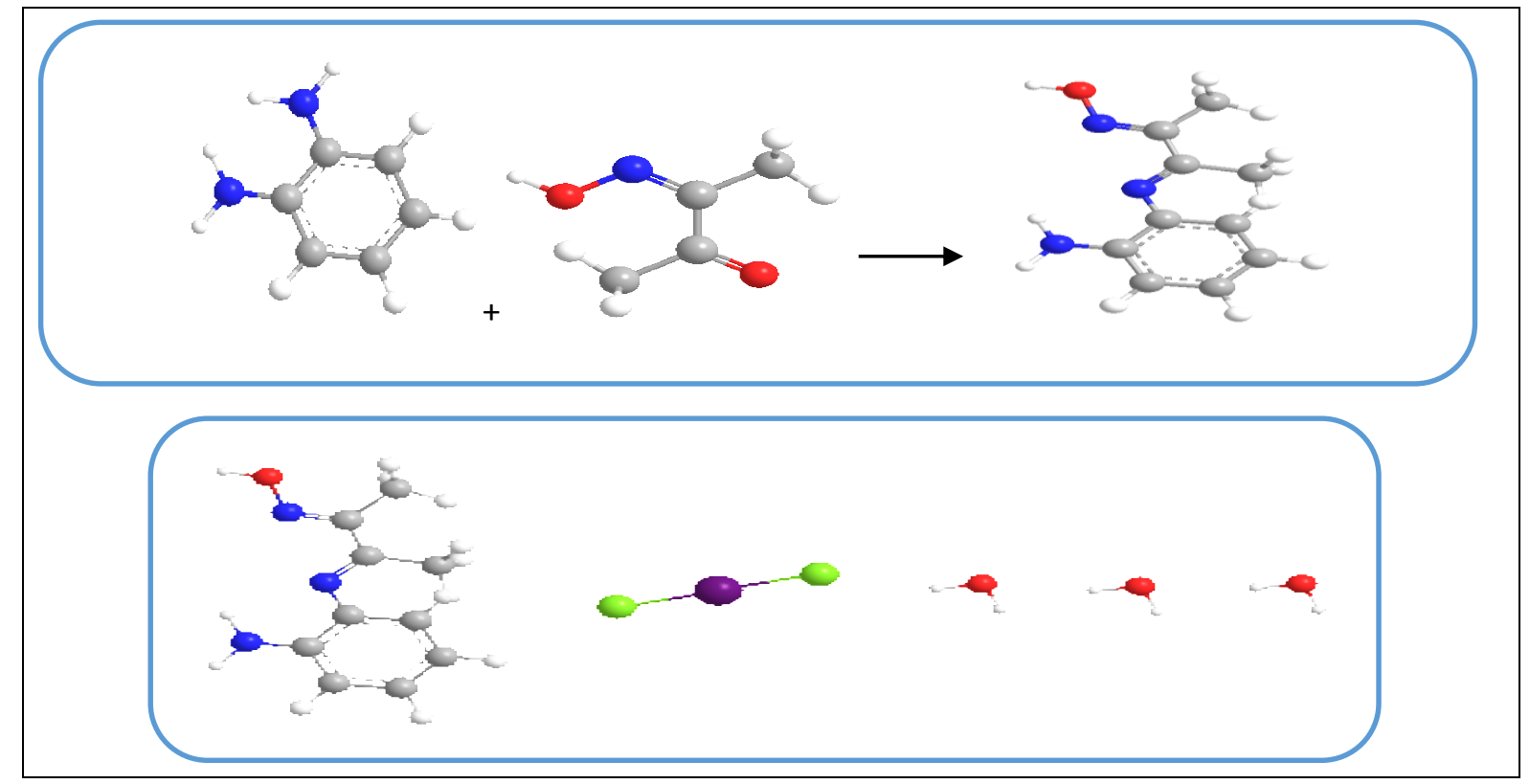

*Corresponding author's E-mail address: abdsalam_1956@yahoo.com 


\section{Introduction}

Schiff bases compounds are the contain azomethine group $(-\mathrm{HC}=\mathrm{N}-)$, and were first reported by Hugo Schiff in 1864 [1]. These compounds are also known as anils, imines or azomethines. It is usually formed by condensation of ketone or an aldehyde with a primary amine [2]. Schiff bases are the most widely used organic compounds. They have been shown to exhibit a broad range of biological activities, including antifungal, antibacterial, antimalarial, antiproliferative, anti-inflammatory, antiviral, and antipyretic properties. This study summarizes the synthesis and biological activities of Schiff bases and their chelates [3]. Ligand oxime has been synthesized by condensation 3,3'-diaminobenzedine and phthaldehyde monoxime. The Mn(II), Co(II), $\mathrm{Ni}(\mathrm{II})$ and $\mathrm{Cu}$ (II) chelates, of this ligand have been prepared and characterized using elemental analysis, molar conductance studies, IR, UV, NMR, EPR and magnetic studies. The ligand and chelates, have been screened for their antimicrobial activity against two gramnegative bacteria and fungi, two gram-positive bacteria. The metal chelates were found to possess potent antimicrobial, antifungal activity better than ligand alone [4]. The oxime ligands can exhibit three coordination modes: coordination through $\mathrm{N}$, coordination through $\mathrm{O}$ after deprotonation and coordinate on through $\mathrm{N}$ after deprotonation [5]. Schiff bases and their metal chelates play an important role in the development of coordination chemistry, resulting in an enormous number of publications, has been studied extensively, and have gained much importance recently due to their chelating ability, antimicrobial, antiinflammatory activitiesand anticorrosion [6-9]. Schiff bases used in the fields of industry, medicine, and organic synthesis, analytical, inorganic and chemistry, they used in optical and electrochemical sensors, transition metal complexes of Schiff bases are used in dyes industry for food, leathers, and wood $[10,11]$. Tetra dentate Schiff bases ligand with a $\mathrm{N}_{2} \mathrm{O}_{2}$ donor atom set are well known to coordinate with various metal ions, and this has attracted the interest of many authors. Chelates of Schiff base ligands studied for their oxidative catalysis [12].

\section{Experimental}

\section{Materials}

All the chemicals used in this study were reagent of $\mathrm{BDH}$ or Aldrich including, diacetylmonoxime, $o$-phenylenediamine, ethanol, diethyl ether and dimethyl formamide.

\section{Synthesis of Schiff base}

The Schiff base L was synthesized by adding (5.055 g, 0.05 mmole) of diacetylmonoxime dropwise to $o$-phenylenediamine $(5.408 \mathrm{~g}, 0.05$ mmole) in $50 \mathrm{~mL}$ of absolute ethanol. The reaction mixture was refluxed for three hours. Then the product obtained was allowed to cool at room temperature, filtered and recrystallized from ethanol, and then dried under vacuum to get yellow precipitate (m.p. $199{ }^{\circ}$ C; yield 89\%). The Schiff base formation can be explained as shown in Scheme 1.

Scheme 1. Synthesis of Schiff base (L)/Reaction condition:

Diacetylmonoxime $(5.055$ g, $\quad 0.05 \mathrm{mmol}), \quad o-$

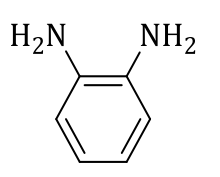<smiles>CC(=[NH+])C(C)=O</smiles><smiles>CC(=NO)C(C)=Nc1ccccc1N</smiles>
phenylenediamine $(5.408$ g, $0.05 \mathrm{mmol})$, absolute ethanol $(50 \mathrm{~mL})$ 
Synthesis of chelates

The Schiff base chelates under investigation were synthesized by adding (2E,3E)-3-((2-aminophenyl)imino)butan-2oneoxime (1.92 g; 0.01 mmole) in $30 \mathrm{~mL}$ absolute ethanol to 0.01 mmole of $\mathrm{MnCl}_{2} \cdot 6 \mathrm{H}_{2} \mathrm{O}$ (2.34 g), $\mathrm{NiCl}_{2} \cdot 6 \mathrm{H}_{2} \mathrm{O}(2.38 \mathrm{~g})$ and $\mathrm{CuCl}_{2} \cdot 2 \mathrm{H}_{2} \mathrm{O}$ $(1.70 \mathrm{~g})$ salts in the same amount of the absolute ethanol. The reaction mixtures were heated under reflux for 3 hours. The chelates were filtered off recrystallized from ethanol and finally kept in a desiccator over silica gel.

\section{Antibacterial activity}

The synthesized complexes were screened for antibacterial activity against Slamonalla typhi., E. coil and Staphylococcus aures using cup plate method $[13,14]$. The test medium
(Muller Hinton agar) poured in Petri dishes and allowed solidify at room temperature. The tested bacteria species suspension prepared in sterile distilled water and streaked on the surface of the agar medium. All the compounds were placed in the wells made by sterile cork borer using $100 \mu \mathrm{L}$ micropipette and allowed to diffuse. The plates were incubated at $37{ }^{\circ} \mathrm{C}$ for $24 \mathrm{~h}$. The inhibition zone formed around the cups were measured in mm.

Wt. of sample in gram $=\mathrm{M}$. wt. $\times \mathrm{M} \times \mathrm{V} \mathrm{mL} / 1000$

Wt. of sample in gram $=$ M. wt. $\times 0.1 \times 1 \mathrm{~mL} / 1000$

\section{Results and discussions}

The reaction between the diacetylmonoxime and $o$-phenylenediamine yields only one product (Scheme 1).

Table 1. Elemental analysis and some physical properties of the Schiff base (L) and its chelates

\begin{tabular}{|c|c|c|c|c|c|c|c|c|}
\hline \multirow{2}{*}{ Compound/Chelates } & \multirow{2}{*}{ Colour } & \multirow{2}{*}{ M. wt. } & \multirow{2}{*}{$\begin{array}{l}\text { M.P. } \\
{ }^{\circ} \mathrm{C}\end{array}$} & \multicolumn{3}{|c|}{ \%Calc. (Found) } & \multirow{2}{*}{$\begin{array}{c}\Lambda \\
(\mu \mathrm{s})\end{array}$} & \multirow{2}{*}{ BM } \\
\hline & & & & $\mathrm{C} \%$ & $\mathrm{H} \%$ & N\% & & \\
\hline $\mathrm{L}\left(\mathrm{C}_{10} \mathrm{H}_{13} \mathrm{~N}_{3} \mathrm{O}\right)$ & Yellow & 191.23 & 199 & $\begin{array}{c}62.81 \\
(62.01)\end{array}$ & $\begin{array}{c}6.85 \\
(7.07)\end{array}$ & $\begin{array}{c}21.97 \\
(22.29)\end{array}$ & - & - \\
\hline$\left[\mathrm{MnL}\left(\mathrm{H}_{2} \mathrm{O}\right)_{2} \mathrm{Cl}_{2}\right] \mathrm{H}_{2} \mathrm{O}$ & $\begin{array}{c}\text { Yellowish } \\
\text { brown }\end{array}$ & 371.12 & $250>$ & $\begin{array}{c}32.36 \\
(32.40)\end{array}$ & $\begin{array}{c}5.16 \\
(4.71)\end{array}$ & $\begin{array}{c}11.32 \\
(11.14)\end{array}$ & 13 & 5.56 \\
\hline$\left[\mathrm{NiLCl}_{2}\right]\left(\mathrm{H}_{2} \mathrm{O}\right)_{3}$ & Red & 374.87 & 245 & $\begin{array}{c}32.04 \\
(32.67)\end{array}$ & $\begin{array}{c}5.11 \\
(4.71)\end{array}$ & $\begin{array}{c}11.21 \\
(11.14)\end{array}$ & 21 & 0.0 \\
\hline$\left[\mathrm{CuL}\left(\mathrm{H}_{2} \mathrm{O}\right)_{2} \mathrm{Cl}_{2}\right]\left(\mathrm{H}_{2} \mathrm{O}\right)_{2}$ & $\begin{array}{c}\text { Dark } \\
\text { brown }\end{array}$ & 379.74 & 232 & $\begin{array}{c}31.63 \\
(31.51)\end{array}$ & $\begin{array}{c}5.04 \\
(4.72)\end{array}$ & $\begin{array}{c}11.07 \\
(10.57)\end{array}$ & 27 & 1.87 \\
\hline
\end{tabular}

Figure 1. Mass spectrum of Schiff base

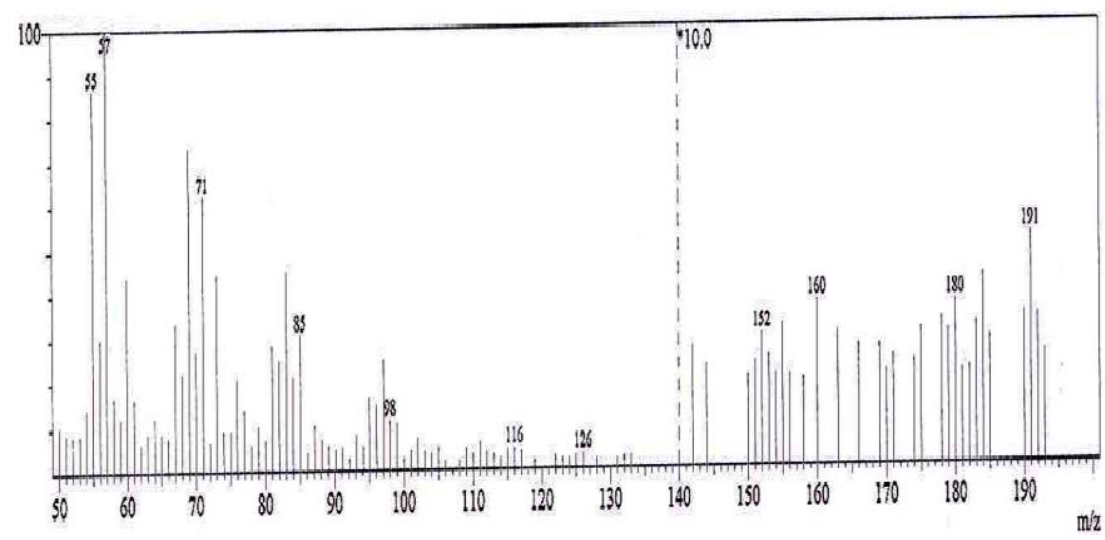


Figure 2. ${ }^{1} \mathrm{H} \quad \mathrm{NMR}$ spectrum of the Schiff base

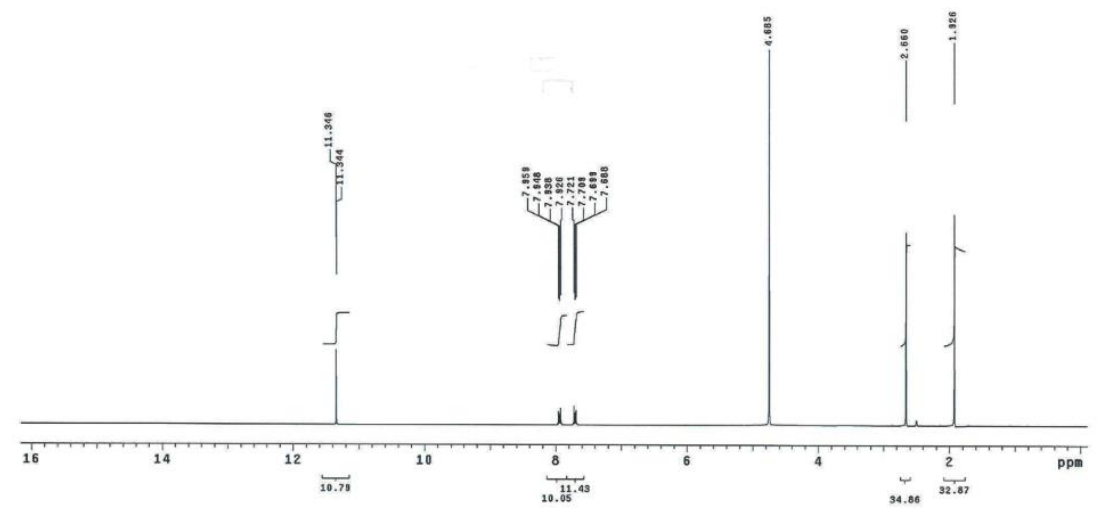

Microanalysis and molar conductance measurements

Some physical properties and elemental analysis data of the Schiff base and its chelates are summarized in Table 1 , where the results confirm the proposed composition. The synthesized chelates were formed in 1:1 (M:L) ratio. The obtained molar conductance values of the complexes in DMF solvent lie in the range of $13-27 \mathrm{ohm}^{-1} / \mathrm{cm}^{2} / \mathrm{mol}^{-1}$ indicating their chelates of $\mathrm{Mn}(\mathrm{II}), \mathrm{Ni}(\mathrm{II})$ and $\mathrm{Cu}(\mathrm{II})$ are non-electrolytic [15].

\section{Mass spectrum of Schiff base}

The mass spectral data of the Schiff base ligand are demonstrated in Figure 1. Molecular ion showed peaks, which were in good agreement with the expected values [16]. The mass spectrum of the Schiff base gives a peak at $191 \mathrm{~m} / z$.

\section{Proton nuclear magnetic resonance spectrum} of ligand

Proton nuclear magnetic resonance spectrum of $L$

The ${ }^{1} \mathrm{H}-\mathrm{NMR}$ spectrum recorded in $d_{6}$ DMSO solvent on a Jeol-90 Fourier Transform (200 MHz). Shows some singlet signals (Figure 3 ) at 11.346, 7.959-7.688, $4.685,2.660$ and $1.926 \mathrm{ppm}$, downfield of TMS, assignable to the protons of $\mathrm{OH}(\mathrm{NOH})$, phenyl ring, $v \mathrm{NH} 2, \quad v \mathrm{CH} 3$ and $v \mathrm{CH} 3$ respectively [17].

\section{Electronic spectra}

The electronic absorption spectra of the Schiff base and its chelates under investigation were recorded using Nujol mull on a Unicom model UV2 spectrophotometer. The electronic spectral data of the schiff base and its chelates under study are shown in (Figures 3-6). The Schiff base ligand spectrum exhibits two absorption signals at $40733 \mathrm{~cm}^{-1}$, $39138 \mathrm{~cm}^{-1}$, attributed to $\pi \rightarrow \pi^{*}$ and $n \rightarrow \pi^{*}$ transitions respectively [18]. The electronic absorption spectrum of Mn(II) chelate show two bands at $48899 \mathrm{~cm}^{-1}, 39062 \mathrm{~cm}^{-1}$ attributed to $\pi \rightarrow \pi^{*}$ and $n \rightarrow \pi^{*}$ transitions, and two bands at $24270 \mathrm{~cm}^{-1}$ and $16124 \mathrm{~cm}^{-1}$ which is due to $\mathrm{d}-\mathrm{d}$ transition for octahedral geometry $[19,20]$. The electronic absorption spectrum of $\mathrm{Ni}$ (II) show a band at $38986 \mathrm{~cm}^{-1}$ attributed to $\pi \rightarrow \pi^{*}$ transitions and two bands at $19607 \mathrm{~cm}^{-1}$ and at $16260 \mathrm{~cm}^{-1}$ due to $3 \mathrm{~A} 2 \mathrm{~g}(\mathrm{~F}) \rightarrow 3 \mathrm{~T} 1 \mathrm{~g}(\mathrm{~F})$ and $3 \mathrm{~A} 2 \mathrm{~g}(\mathrm{~F}) \rightarrow 3 \mathrm{~T} 1 \mathrm{~g}$ (P) (d-d) transitions which suggest an octahedral geometry [21]. Cu(II) chelate spectrum exhibits two absorption bands at $47505 \mathrm{~cm}^{-1}$ and $39138 \mathrm{~cm}^{-1}$ attributed $\pi \rightarrow \pi^{*}$ and $n \rightarrow \pi^{*}$ transitions, and show bands at $24390 \mathrm{~cm}^{-1}$ and at $16129 \mathrm{~cm}^{-1}$ mainly due to $2 \mathrm{Eg} \rightarrow 2 \mathrm{~T} 2 \mathrm{~g}$ transition. The observed data gave evidence for the octahedral geometry [22] of the chelate. 
Table 2. IR and electronic spectral data of the Schiff base and its chelates

\begin{tabular}{ccccccc} 
Ligand/ chelates & & \multicolumn{4}{c}{ IR $\left(\mathrm{cm}^{-1}\right)$} & \\
& $v 0 \mathrm{H}$ & $v \mathrm{NH} 2$ & $v \mathrm{C}=\mathrm{N}$ & $v \mathrm{M}-\mathrm{N}$ & $v \mathrm{M}-\mathrm{O}$ & $\lambda_{\max }\left(\mathrm{cm}^{-1}\right)$ \\
$\mathrm{L}\left(\mathrm{C}_{10} \mathrm{H}_{13} \mathrm{~N}_{3} \mathrm{O}\right)$ & 3443 & 3348 & 1619 & - & - & 39138,40733 \\
{$\left[\mathrm{MnL}\left(\mathrm{H}_{2} \mathrm{O}\right)_{2} \mathrm{Cl}_{2}\right] \mathrm{H}_{2} \mathrm{O}$} & 3476 & 3416 & 1630 & 595 & 531 & $48899,39062,16124$ \\
& & & & & & 24270 \\
{$\left[\mathrm{NiLCl}_{2}\right]\left(\mathrm{H}_{2} \mathrm{O}\right)_{3}$} & 3474 & 3412 & 1624 & 623 & 585 & 38986,19607 \\
& & & & & & 16260 \\
{$\left[\mathrm{CuL}\left(\mathrm{H}_{2} \mathrm{O}\right)_{2} \mathrm{Cl}_{2}\right]\left(\mathrm{H}_{2} \mathrm{O}\right)_{2}$} & 3413 & 3326 & 1615 & 602 & 538 & 47505,39138 \\
\hline
\end{tabular}

Figure 3. UV spectrum of the free ligand $\mathrm{L}$

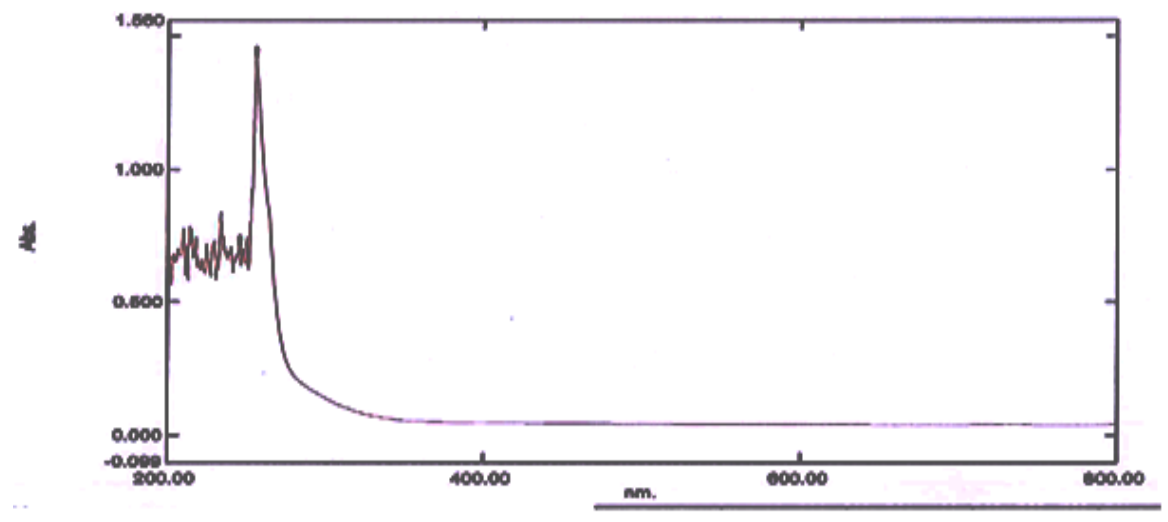

Figure 4. Electronic spectrum of $\left[\mathrm{MnL}\left(\mathrm{H}_{2} \mathrm{O}\right)_{3}\right] \mathrm{Cl}_{2}$

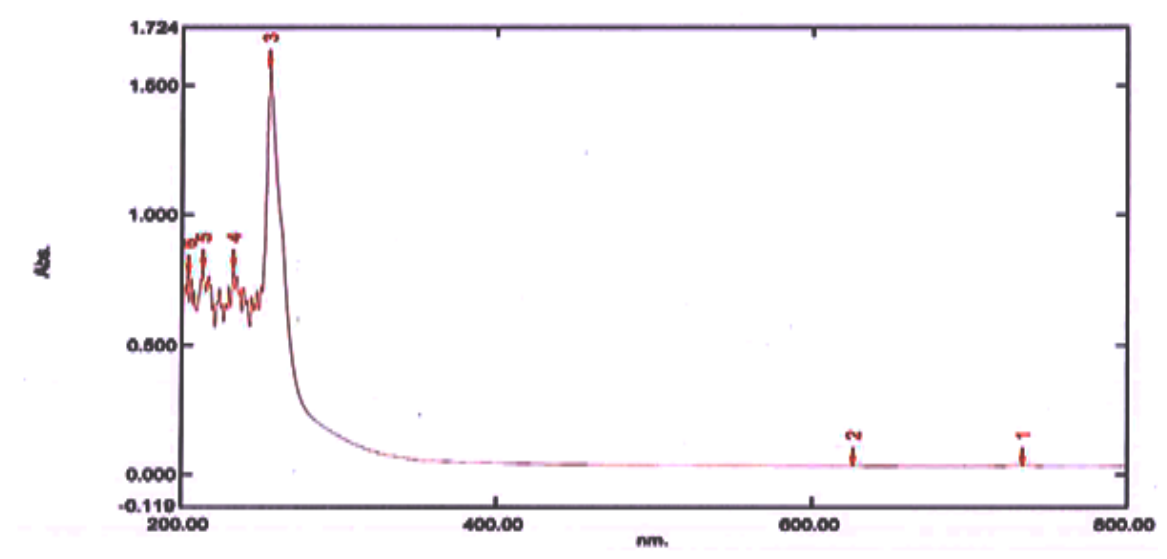

Figure 5. Electronic spectrum of $\left[\mathrm{NiL}\left(\mathrm{H}_{2} \mathrm{O}\right)_{3}\right] \mathrm{Cl}_{2}$

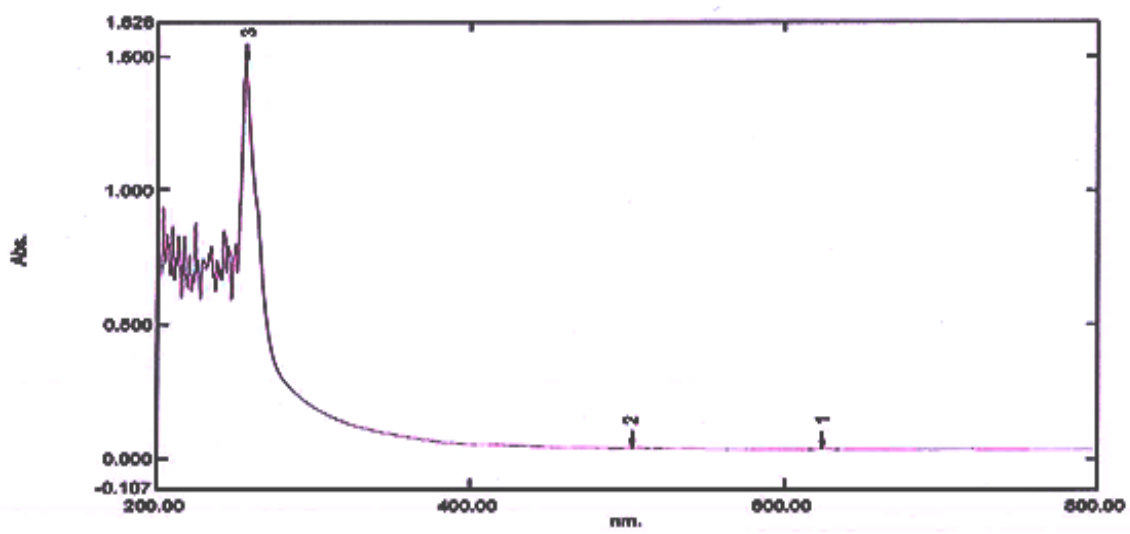


Figure 6. Electronic spectrum of $\left[\mathrm{CuL}\left(\mathrm{H}_{2} \mathrm{O}\right)_{2} \mathrm{Cl}\right]\left(\mathrm{H}_{2} \mathrm{O}\right) \mathrm{Cl}$

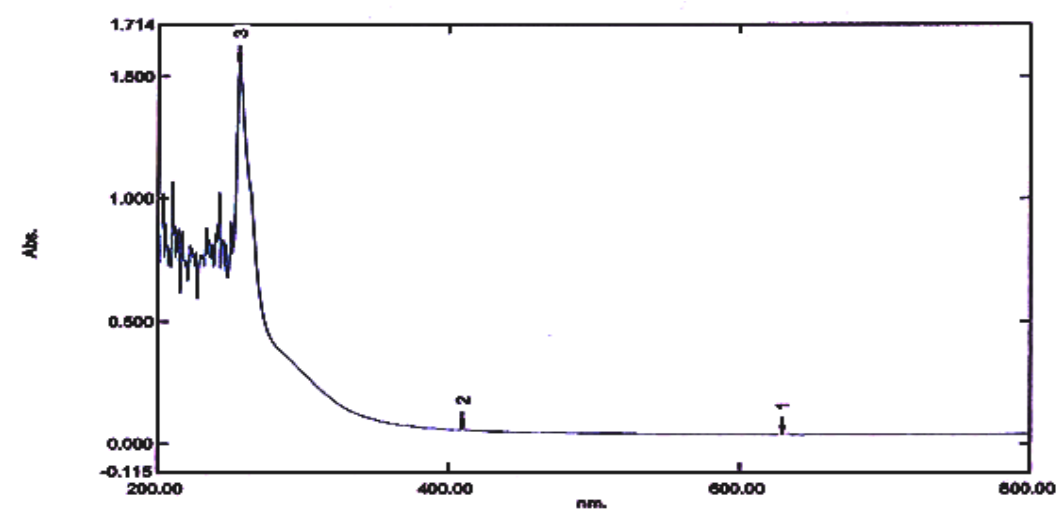

Magnetic susceptibility measurements

The magnetic moment of $\mathrm{Mn}$ (II) chelate was $5.65 \mathrm{BM}$, suggesting the high spin sixcoordinated octahedral arrangement of the ligand around the metal ion [23,24]. The Ni(II) chelate has magnetic moment value of 0.00 $\mathrm{BM}$ indicating a square planar configuration [25]. The magnetic moment value of $\mathrm{Cu}$ (II) chelate is $1.79 \mathrm{BM}$ which suggests a distorted octahedral geometry around the metal ion [26].

\section{IR spectra}

The IR spectra of the ligand and its chelates with $\mathrm{Mn}^{2+}, \mathrm{Ni}^{2+}$ and $\mathrm{Cu}^{2+}$ were recorded in the solid state in the rang $400-4000 \mathrm{~cm}^{-1}$ using $\mathrm{KBr}$ disc on a Perkin-Elmer 1430 ratio recording infrared spectrophotometer (Figures 7-10). The IR spectral data are present in Table 2. A verification of the structures of the metal chelates can be easily achieved by comparing the IR spectrum of the free ligand with those of chelates [27]. When a Schiff base ligand is coordinated to metal ion at least one additional atom is introduced into the ligand vibrating system. It is thus expected that bond lengths, angles and interacting forces within the ligand would be altered even at least slightly. The IR spectrum of the Schiff base display three bands at $3443 \mathrm{~cm}^{-1}$ attributed to $\mathrm{OH}$ group, $3348 \mathrm{~cm}^{-1}$ attributed $\mathrm{NH} 2$ group and a band at $1619 \mathrm{~cm}^{-1}$ attributed to $\mathrm{C}=\mathrm{N}$ group [28-30]. The shifting of $v(\mathrm{C}=\mathrm{N})$ group vibration in all chelates indicates the participation of nitrogen atom during chelates $[31,32]$. Chelates IR spectrum revealed broad bands at the range of $3413-3476 \mathrm{~cm}^{-1}$ that attributed to stretching vibration $\mathrm{OH}$ of coordinated water molecules banding with chelates formation [33]. The NH2 group is not participating in coordination 34. New bands observed at 538-585 $\mathrm{cm}^{-1}$ and at 595-623 $\mathrm{cm}^{-1}$ which could be attributed to $v(\mathrm{M}-0)$ and $v(\mathrm{M}-$ N) vibrations $[35,36]$.

Figure 7. IR spectrum of the Schiff base

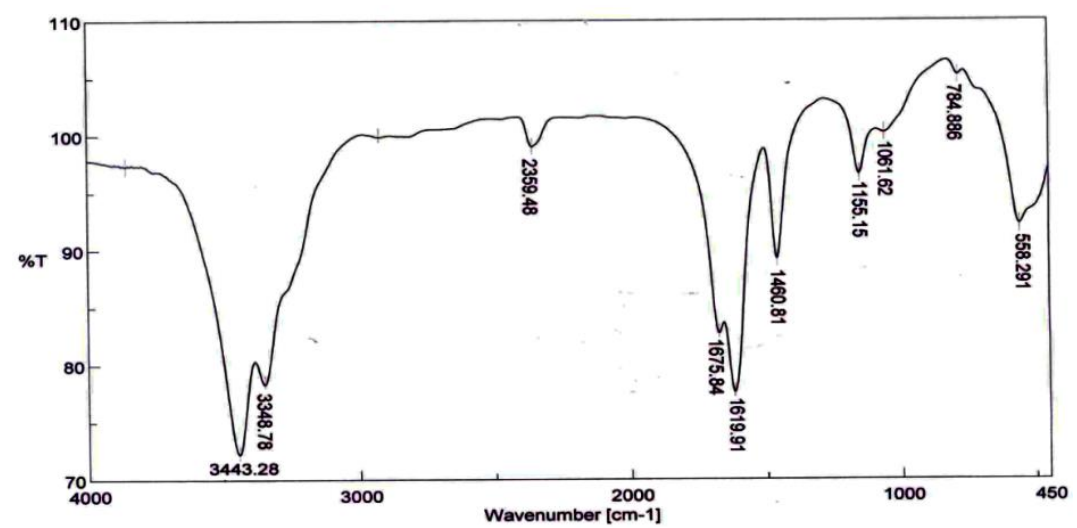


Figure 8. IR spectrum of $\left[\mathrm{MnL}\left(\mathrm{H}_{2} \mathrm{O}\right)_{3}\right] \mathrm{Cl}_{2}$

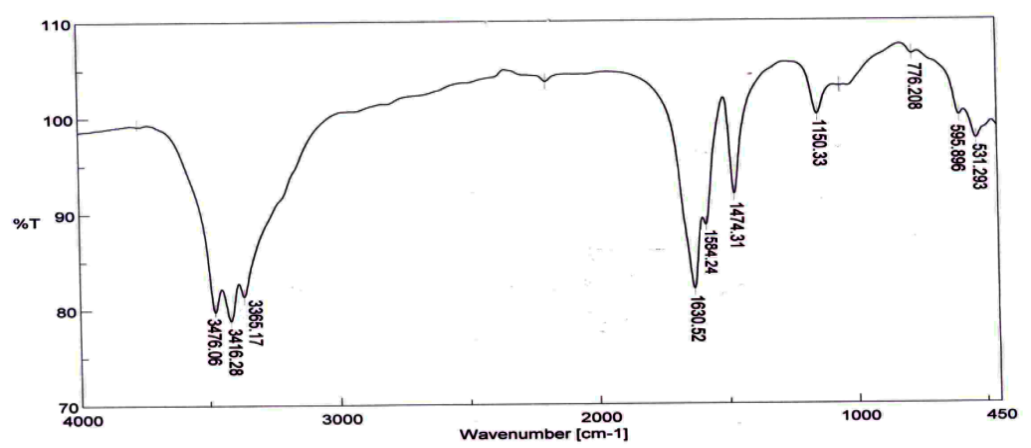

Figure 9. IR spectrum of $\left[\mathrm{NiL}\left(\mathrm{H}_{2} \mathrm{O}\right)_{3}\right] \mathrm{Cl}_{2}$

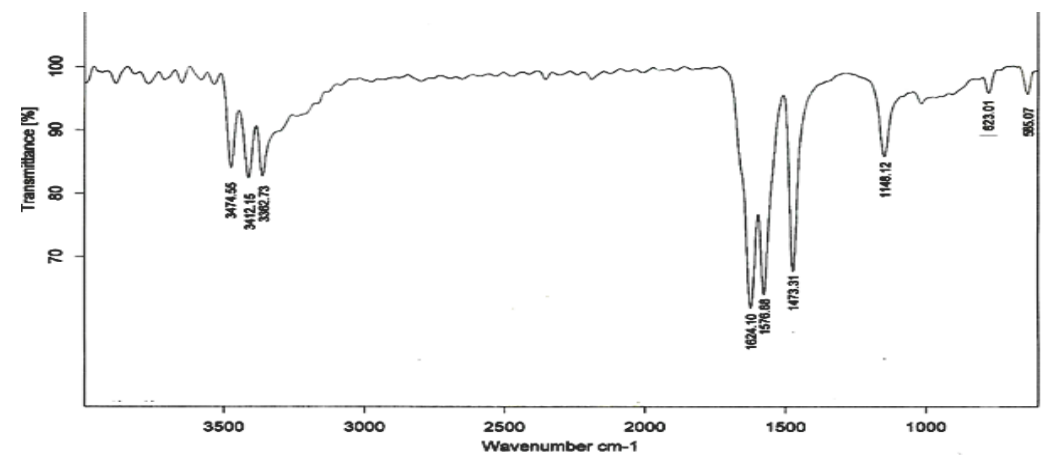

Figure 10. IR spectrum of $\left[\mathrm{CuL}\left(\mathrm{H}_{2} \mathrm{O}\right)_{2} \mathrm{Cl}\right]\left(\mathrm{H}_{2} \mathrm{O}\right) \mathrm{Cl}$

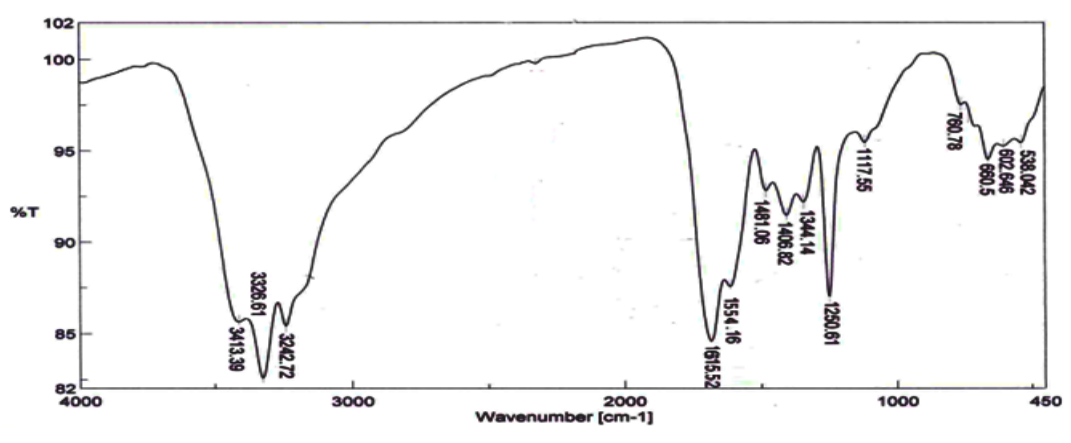

Table 3. Antibacterial activity results $(\mathrm{mm})$ for the Schiff base and its complexes

\begin{tabular}{cccc} 
& \multicolumn{3}{c}{ Bacteria, inhibition zone $(\mathrm{mm})$} \\
Ligand and its chelates & Slamonalla typhi & E. Coli & Staphylococci \\
$\mathrm{L}\left(\mathrm{C}_{10} \mathrm{H}_{13} \mathrm{~N}_{3} \mathrm{O}\right)$ & 15 & 18 & - \\
{$\left[\mathrm{MnL}\left(\mathrm{H}_{2} \mathrm{O}\right)_{3}\right] \mathrm{Cl}_{2}$} & 9 & 13 & 19 \\
{$\left[\mathrm{NiL}\left(\mathrm{H}_{2} \mathrm{O}\right)_{3}\right] \mathrm{Cl}_{2}$} & 13 & 23 & 15 \\
{$\left[\mathrm{CuL}\left(\mathrm{H}_{2} \mathrm{O}\right)_{2} \mathrm{Cl}\right]\left(\mathrm{H}_{2} \mathrm{O}\right) \mathrm{Cl}$} & 13 & 12 & 11 \\
\hline
\end{tabular}

Scheme 2. $\left[\mathrm{MnL}\left(\mathrm{H}_{2} \mathrm{O}\right)_{2} \mathrm{Cl}_{2}\right] \mathrm{H}_{2} \mathrm{O}$

Reaction condition: (2E, 3E)-3- ((2-amino phenyl) imino) butane-2-one oxime (1.92 g, $0.01 \mathrm{mmole})$, $\mathrm{MnCl} 2.6 \mathrm{H} 2 \mathrm{O}$ (2.34 g, $0.01 \mathrm{mmole})$, absolute ethanol $(60 \mathrm{~mL})$

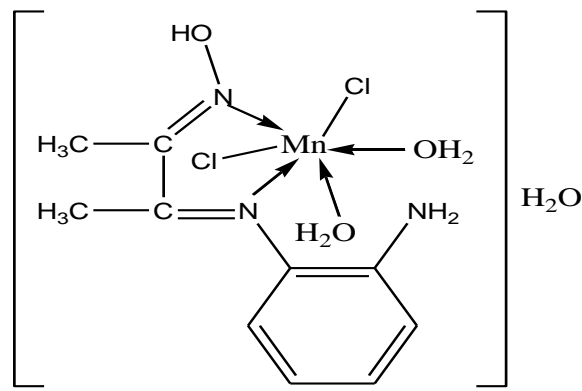


Anti-bacterialactivity results

The ligand

(2E.3E)-3- $((2$

aminophenyl)imino)-butan-2-one oxime (L) and its synthesized chelates were screened for their possible antibacterial activities against three types of bacteria, Slamonalla typhi, E. Coli, and Staphylococci. The ligand and its chelates showed moderate to good antibacterial activities against all used types of bacteria these activities were performed by

Scheme3. $\left[\mathrm{NiLCl}_{2}\right]\left(\mathrm{H}_{2} \mathrm{O}\right)_{3}$

Reaction condition: (2E, 3E)-3-((2-amino phenyl) imino) butane-2-one oxime (1.92 g, 0.01 mmole), $\mathrm{NiCl}_{2} .6 \mathrm{H}_{2} \mathrm{O}$ ( $2.38 \mathrm{~g}, 0.01 \mathrm{mmole}$ ), absolute ethanol $(60 \mathrm{~mL})$

Scheme 4. $\left[\mathrm{CuL}\left(\mathrm{H}_{2} \mathrm{O}\right)_{2} \mathrm{Cl}_{2}\right]\left(\mathrm{H}_{2} \mathrm{O}\right)_{2}$

Reaction condition: (2E, 3E)-3-((2-amino phenyl) imino) butane-2-one oxime $(1.92 \mathrm{~g}$, 0.01 mmole), $\mathrm{CuCl}_{2} .6 \mathrm{H}_{2} \mathrm{O}(1.70 \mathrm{~g}, 0.01$ mmole), absolute ethanol ( $60 \mathrm{~mL})$.

\section{Conclusion}

In this research study, we describe the synthesis, chraracterization and antibacterial properties of the complexes. Three novel transition metal complexes of $\mathrm{Mn}(\mathrm{II}), \mathrm{Ni}(\mathrm{II})$ and $\mathrm{Cu}(\mathrm{II})$ with Schiff base derived from diecetylemonoxime with $o$-phenylenediamine were synthesized by condensation process. The synthesized compounds were characterized using several techniques: Elemental analysis, Magnetic moment measurements, Molar conductivity cup plate method. Inhabitation zone were recorded by measuring the diameter of inhabitation zone in $\mathrm{mm}$ at the end of $24 \mathrm{~h}$ [37]. At room temperature, the results of antibacterial study are tabulated in Table 3 . The widest inhabitation zone was formed around E. coil (23 mm), followed by (19 $\mathrm{mm})$ for Staphylococci and the least inhibitory effects were observed for Slamonalla typhi and Staphylococci (9 mm). The (-) means no inhibition [38].
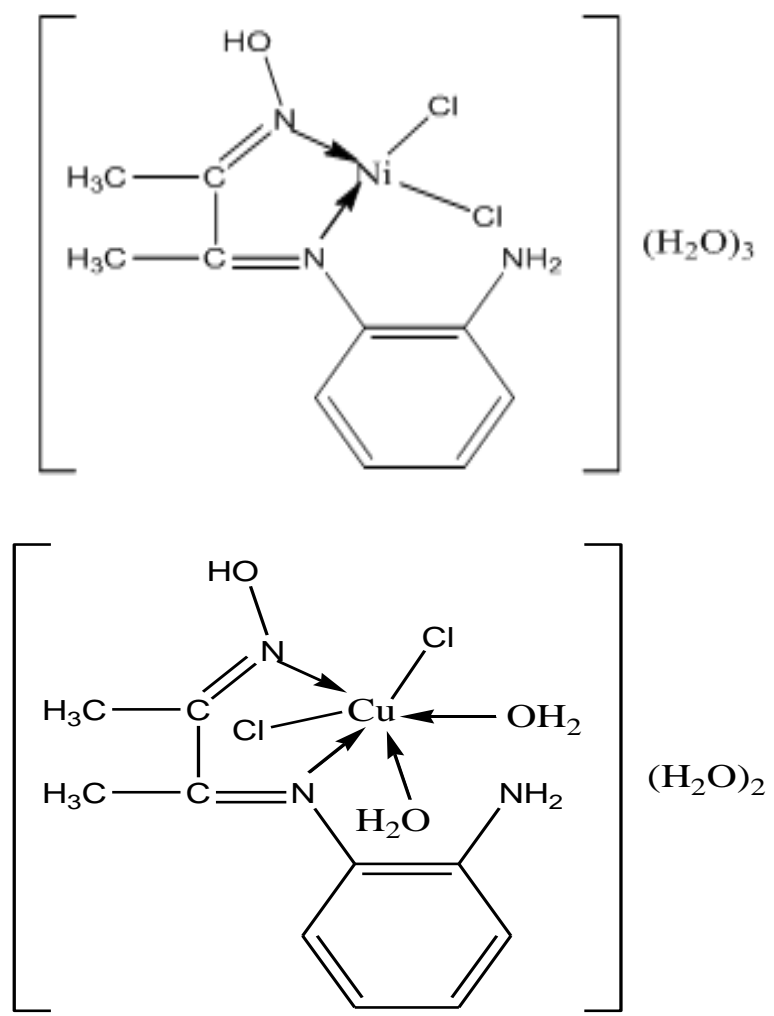

measurements, Mass spectral, H-NMR spectroscopy, UV-Vis spectroscopy and IR spectrometer. Based on the analytical data the synthesized compounds $\mathrm{Mn}(\mathrm{II}), \mathrm{Ni}(\mathrm{II})$ and $\mathrm{Cu}(\mathrm{II})$ Schiff base chelates suggests 1:1 $\{\mathrm{M}: \mathrm{L}\}$ molar ratio and exhibits an octahedral structure for $\mathrm{Mn}(\mathrm{II}), \mathrm{Cu}(\mathrm{II})$ complexes and squar planer structure for $\mathrm{Ni}(\mathrm{II})$ complex as shown above (Schemes 2-4). The synthesized compounds were screened against three types of bacteria showing moderate to good activities against all used types of bacteria. 


\section{Acknowledgment}

The authors are thankful to Mr.Aluwah Rashad Aulwah technician at Chemistry Department Faculty of Science, Sebha University for providing laboratory facilities during this work.

\section{Disclosure statement}

No potential conflict of interest was reported by the authors.

\section{ORCID}

\section{A. Hamil (D): 0000-0002-6364-8221}

\section{A. A. Almutaleb (D): 0000-0002-7245-5798}

\section{References}

[1] P. Nagpal, R.V. Singh, Appl. Organomet. Chem., 2004, 18, 221-226.

[2] M. Abirami, V. Nadaraj, Int. J. ChemTech. Res., 2014, 6, 2534-2538.

[3] W. Al Zoubi, Int. J. Org. Chem., 2013, 3, 7395.

[4] P. Jayaseelan, S. Prasad, S. Vedanayaki, R. Rajavel, Eur. J. Chem., 2011, 2, 480-484.

[5] T. Radhakrishnan, S.P. Nair, G.A. Kolawole, N. Revaprasadu, G.E. Hawkes, M. Motevalli, P. O'Brien, Magnet. Resonan. Chem., 2007, 45, 59-64.

[6] N. Mahalakshmi, R. Rajavel, Asian J. Biochem. Pharmaceut. Res., 2011, 1, 525543

[7] F. Khan, S. Khan, A. Athar, W. Ahmed, Z. Haq, Z. Khan, Amer. Eur. J. Agric. Environ. Sci., 2015, 15, 216-219.

[8] A.O. Sobola, G.M. Watkins, B.B. Van, South Afr. J. Chem., 2014, 67, 45-51.

[9] N. Akbolat, A. Yıldız, H. Temel, S. Ilhan, G. Gul, DUFED, 2012, 1(1), 15-22.

[10] G. Fareed, M.A. Versiani, N. Afza, N. Fareed, L. Iqbal, M. Lateef, Int. J. Curr. Pharm. Res., 2013, 5, 61-64.

[11] S. Kumar, D.N. Dhar, P. Saxena, J. Scientif. Indust. Res., 2009, 68, 181-187.
[12] L. Jian-ning, W. Bo-wan, Z. Bing, L. Yongchun, Turk. J. Chem., 2006, 30, 41-48.

[13] F. Kavana, Analytical microbiology, New York: Academic Press, Elsevier; 1963, 313.

[14] S.S. Panda, P.V.R. Chowdary, B.S. Jayashree, Ind. J. Pharm. Sci., 2009, 71, 684-687.

[15] K.M. Khalifa, A.M. Hamil A. Gasem, A. Abdulsalam, J. Chem., 2010, 7, 49-54.

[16] A.M. Hamil, M. Abdelkarem, M.M. Elajaily, Synthesis, 2012, 4, 682-685.

[17] M.G. Derebe, V.J.T. Raju, N. Retta, Bull. Chem. Soc. Ethiop., 2002, 16, 53-64.

[18] K. Amerada, R. Rajavel, J. Chem., 2012, 9, 481-486.

[19] P.S. Deshmukh, A.R. Kaul, J.N. Bhojane, World Appl. Sci. J., 2010, 9, 13011305.

[20] N.P. Singh, J. Singh, J. Chem., 2012, 9, 1835-1842.

[21] N. Raman, S. Ravichandran, C. Thangaraja, J. Chem. Sci., 2004, 116, 215-219.

[22] B. Anupama, M. Padmaja, C.G. Kumari, J. Chem., 2012, 9, 389-400.

[23] M.H. Soliman, G.G. Mohamed, Spectrochim. Acta A. Mol. Biomol. Spectrosc., 2013, 107, 8-15.

[24] P. Mittal, S. Joshi, V. Panwar, V. Uma, Int. J. ChemTech. Res., 2009, 1, 225-232.

[25] M. Rahangdale, G. Pethe, A. Yaul, A. Aswar, Res. J. Pharm. Biol. Chem. Sci., 2011, 2, 341-348.

[26] N. Raman, Y.P. Raja, A. Kulandaisamy, J. Chem. Sci., 2001, 113, 183-189.

[27] E.M. Ramadthan, Iraqi National J. Chem., 2013, 50, 154-166.

[28] U. Çakır, H. Temel, S. İhan, H.I. Uğraş, Spectroscopy lett., 2003, 36, 429-440.

[29] S. Annapoorani, C.N. Krishnan, Int. J. ChemTech Res., 2011, 3, 1962-1968.

[30] S.H. Baiu, M.M. El-Ajaily, N.M. El-Barasi, Asian J. Chem., 2009, 21, 5-10.

[31] K. Mounika, A. Pragathi, C. Gyanakumari, J. Scientif. Res., 2010, 2, 513-524. 
[32] G.G. Mohamed, M.M. Omar, A.M. Hindy, Turk. J. Chem., 2006, 30, 361-382.

[33] M.M. El-Ajaily, F.M. El-Saied, Asian J. Chem., 2007, 19, 4433-4437.

[34] D.M. Boghaei, M. Lashanizadegan, J. Sci. I. R. I., 2000, 11, 301-304.

[35] D. Kumar, S. Chadda, J. Sharma, P. Surain, Bioinorg. Chem. Appl., 2013, 2013, 981764.

How to cite this manuscript: Abdusalam Hamil, Kalifa Mosbah Khalifa, Arabya Abdelsalam Almutaleb, Synthesis, Characterization and Antibacterial Activity Studies of Some Transition Metal Chelates of Mn(II), Ni(II) and Cu(II) with Schiff Base Derived from Diacetylmonoxime with $O$-phenylenediamine, Adv. J. Chem. A, 2020, 3(4), 524-533. 